バリアフリー環境整備前後における利用者の環境評価の変化 東京都心近傍の鉄道駅の利用者評価からの考察

\title{
CHANGES IN USER EVALUATION BEFORE AND \\ AFTER MAKING ACCESSIBLE ENVIRONMENT
}

- Case study on changes in user evaluation of railway station located near the centre of Tokyo -

\author{
大村 薰*, 佐藤克志** \\ Kaoru OMURA and Katsushi SATO
}

\begin{abstract}
The purpose of this study is to clarify changes in user evaluation before and after making a railway station accessible environment. The findings are summarized below: 1) The level of user-friendly satisfaction was raised regardless of user attribute by improving accessibility. 2) Concerning elements of access features, 'satisfied' evaluation of almost all features were increased soon after the improvement project completed. However some features changed its evaluation from 'satisfied' to 'average' as time passed.3) Comprehensive evaluation of the railway station consist of four factors, such as 'Safety', 'Clear information', 'Accessible pass of travel' and 'Toilet'. Comprehensive evaluation is greatly influenced by 'Accessible pass' among four factors.
\end{abstract}

Keywords: Accessible environment, Railway station, User evaluation, Year to year changes, questionnaire バリアフリー環境，鉄道駅，利用者評価，経年変化、アンケート調査

\section{1.はじめに}

\section{$1-1$. 研究の背景と目的}

「高齢者、身体障害者等が円滑に利用できる特定建築物の建築の 促進に関する法律（ハートビル法：1994 年)」や「高齢者、身体障 害者等の公共交通機関を利用した移動の円滑化の促進に関する法律 (交通バリアフリー法 : 2000 年)」の施行、また両者を統合・拡充 した「高齢者・障害者等の移動等の円滑化の促進に関する法律（バ リアフリー法 : 2006 年)」の制定、施行などを背景として、高齢者 や障害者を含む全ての生活者を対象とした生活関連施設の移動・利 用円滑化のための整備が多くの自治体や民間事業者によって進めら れるようになった。

バリアフリー法制定の政策根拠として位置づけられている「ユニ バーサルデザイン政策大綱〈国土交通省：2005 年〉」では、利用者 の目線に立った参加型社会の構築を目指し、持続的・段階的な取組 みを推進すること、すなわち住民参加型の計画(Plan) ・ 実行(Do) • 評価(Check) ・改善(Action)のサイクル（以下 PDCA サイクル）に よるスパイラルアップの環境改善を求めている。確かに、バリアフ リー法に基づく基本構想策定の過程では、当事者ニーズを把握する ため高齢者や障害者を含む住民参加（現地点検やワークショップな
ど）が実践されてきているが、住民の参加が形式的なもので終わっ ているなど自治体間に差があるといった報告 ${ }^{1 ） 2 （ 3) ~ も み ら れ る 。 ~}$

また、PDCA サイクルによるスパイラルアップを実現するために はバリアフリー環境整備後のフォローアップが必要不可欠であるに もかかわらず、事業の進捗確認程度に留まり、バリアフリー化され たことによって施設の利用のしや寸さがどのように変化したかなど、 利用者の視点に立った評価と課題の抽出が積極的に行われていると は言い難い状況である注1)。利用者の視点に立ったスパイラルアッ プの環境改善を実践していくためには、改善事業が実施された環境 について日常的に利用する人々による評価を継続的に実施し、問題 は解消されたのかどうか、新たな問題が発生していないか、また改 善後にも問題が指摘される場合にはその問題の原因は何かを明らか にしていくことが必要である。

本研究では、その第一段階として、バリアフリー法において生活 関連施設として重要な位置にある鉄道駅施設（バリアフリー法でい う「鉄軌道駅」と同義）を対象とし、移動・利用円滑化のための環 境整備（以下、バリアフリー環境整備）の前後における駅利用者の 環境評価の変化の傾向を明らかにすることを目的とする。
* 日本女子大学家政学部住居学科 助手 ·修士(家政学)

** 日本女子大学家政学部住居学科 准教授·工修 


\section{1-2. 既往研究と本研究の位置づけ}

本研究の対象とした「駅施設の利用者評価」についての既往研究 としては、ユニバーサルデザインの視点から設計されている新設駅 の利用実態をもとに、駅設備の評価と駅の利用しやすさ評価から、 既存駅との比較を行っている研究 ${ }^{4)}$ 、一部の駅設備（エレベーター (以下、E V) 、エスカレーター（以下、E S C) など）に限定して 設置効果を測るために利用者満足度評価を行い、鉄道駅内での設備 設置計画に関する検討を試みた研究 ${ }^{5)}$ 、乗換の際の利便性向上を図 るための方策やその効果を検討することを目的として、駅施設改良 によるさまざまな効果を定量的に評価できる駅施設改良事業評価モ デルの開発を行っている研究 ${ }^{6)}$ 、鉄道駅に導入すべきバリアフリー 整備事項の検討を目的として、新設の福祉型鉄道駅のバリアフリー の現状と利用者が考える駅施設整備における重要項目の分析を行っ ている研究 ${ }^{7)}$ 、「移動施設」「付属施設」「情報提供」に着目し、高齢 者の駅施設利用特性について、利用実態と意識の両面から分析を行 い、駅全体の評価における設備の重要度を明らかにすることによっ て駅施設整備のあり方を検討している研究 ${ }^{8}$ などがあげられるが、 同一の駅施設においてバリアフリー環境整備の前後で利用者評価を 実施し、その変化について言及している研究はない。

\section{2. 研究方法}

本研究では、2005 年の調査開始時にはバリアフリー未整備注 2) で あった鉄道駅を対象とし、周辺住民に対しその駅施設の利用のしや すさに関する調查を行った。その後、基本改修注3) が終了した 2007 年と全面改修が終了した 2009 年に再度、同様の調查を実施した。

\section{$2-1$. 調査対象駅および立地の概要}

バリアフリー整備などの物的な環境整備前後の利用者評価の比較 が近年中に可能と予測された武蔵小山駅（以下、MK駅）を調査対 象地として選定した。MK駅は東京近傍の私鉄沿線に位置し、一般 的な生活駅注4) として位置づけられる。駅前には 3 つの商店街があ り、スーパーマーケットや薬局、青果店などの生活必需品の店舗か らファーストフード店、居酒屋、ゲームセンターなどの遊興施設ま で多業種にわたり約 270 の店舗が軒を並べており、近隣住民の生活 には欠かせない場となっている。またその周辺地域は住宅が中心と なっている。MK駅は、改修前は島式ホーム地上 1 面 2 線であった が、2006 年の基本改修後には島式ホーム地下 2 面 4 線となり、同 年急行列車の停車駅となった。1 日の平均乗降客数は約 45,600 人 (2008 年度)である（表 1 )。また 2009 年 5 月、駅舎の全面改修とと もに駅前広場も整備され、路線バスやタクシー乗場も新設された。

\section{$2-2$. 調査概要}

調查は、2005 年、2007 年、 2009 年ともにMK駅を利用すると想 定される周辺約 $1 \mathrm{~km}$ 範囲内に居住する各住民宅ポストへの無作為の 投函、郵送回収によるアンケート調查として実施した（表 2 )。ま た、アンケート調査の内容は表 3 のとおりである。なお、「駅の利 用しや寸さ : 要素別 5 段階評価」の評価項目については、 $\mathrm{E} V$ など 改修後に新設された設備もあるため、一部異なっている。
表 $1 \mathrm{MK}$ 駅 1 日平均乗降客数経年変化注 5)

\begin{tabular}{lcccc} 
& 2005年 & 2006年 & 2007年 & 2008年 \\
\hline 乗降客数 $/$ 日 & 39,774 & 40,826 & 44,276 & 45,637 \\
前年比増 $(\%)$ & - & 2.6 & 8.5 & 3.1 \\
\hline
\end{tabular}

表 2 アンケート調查の概要

\begin{tabular}{|c|c|c|c|}
\hline & 2005年度調査 & 2007年度調査 & 2009年度調査 \\
\hline 方法 & \multicolumn{3}{|c|}{ 配布:ポスティング / 回収:郵送 } \\
\hline 期間 & $\begin{array}{c}\text { 2005年10月下旬 } \\
\sim 11 \text { 月上旬 }\end{array}$ & $\begin{array}{c}2007 \text { 年8月下旬 } \\
\sim 9 \text { 月上旬 }\end{array}$ & $\begin{array}{c}\text { 2009年5月上旬 } \\
\sim 5 \text { 月下旬 }\end{array}$ \\
\hline 配布数 & 970部 & 800 部 & 1200部 \\
\hline 回収数 & $\begin{array}{c}\text { 113部 } \\
\text { (MK駅利用者47部) }\end{array}$ & 113部 & $\begin{array}{c}\text { 182部 } \\
\text { (MK駅利用者153部) }\end{array}$ \\
\hline 回収率 & $\begin{array}{c}11.6 \% \\
\text { (MK駅利用者4.8\%) }\end{array}$ & $14.10 \%$ & $\begin{array}{c}15.17 \% \\
\text { (MK駅利用者 } 12.8 \% \text { ) }\end{array}$ \\
\hline 対象 & \multicolumn{3}{|c|}{ 尺周辺住民 } \\
\hline
\end{tabular}

表 3 アンケート調査内容

（*は当該年に調査済み項目）

\begin{tabular}{|c|c|c|c|}
\hline アンケート項目一MK駅の利用のしやすさにこついて & 2005 & 2007 & 2009 \\
\hline よ<利用する駅名、利用頻度 & * & * & * \\
\hline 駅までの所要時間、駅までの移動手段 & * & * & \\
\hline 改修前後での利用頻度変化 & & & * \\
\hline \multicolumn{4}{|l|}{ 駅の利用のしやすさ ： 要素別5段階評価（大変利用しやすい 大変利用しづらい） } \\
\hline ロ出入口から改札まで （出入口／階段／ESC／EV／運賃表／券売機） & * & * & * \\
\hline 口改札からホームまで （改札／ホームまでの案内表示/トイレ／階段／ESC／EV） & * & * & * \\
\hline ロホームや乗車するまで (ホーム／ホーム柵／電車とホームの段差·隙間） & * & * & * \\
\hline 駅の利用のしやすさ: 総合評価 (2005では5段階評価、2007および2009は100点満点で評価) & * & * & * \\
\hline 属性: 性別、年齢、歩行能力の程度、住所、居住年数＜2009のみ> & * & * & * \\
\hline
\end{tabular}

表 4 2005, 2007, 2009 MK 駅 改修・設置状況注6)

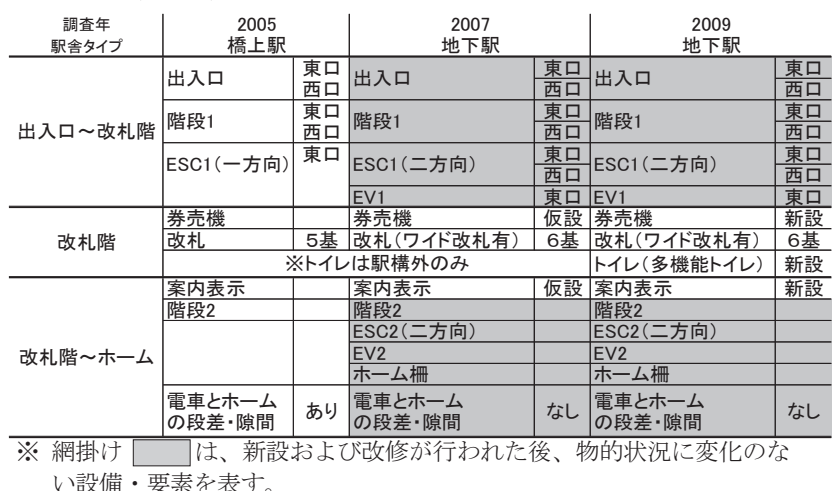

い設備・要素を表す。

\section{3． 調査対象駅のバリアフリー状況}

調查対象としたMK駅の調查時の状況を以下にまとめる。 1）2005 年調查時: 改修前（図 1)：駅舎は橋上タイプであり、出 入口から改札階までは $\mathrm{E} \mathrm{V}$ 未設置（西口は階段のみ）、また改札階 からホームまでは階段のみとなっており、垂直移動に関してバリア フリー化されていない。また、駅舎内にはトイレ未設置であった。 2） 2007 年調查時 : 基本改修後：2006 年 7 月に地下駅への改修が 終了し、東口については出入口に E V (通り抜け型)、階段、 E S C（上り下り 2 方向）が併設された。一方、西口については、階段、 E S C（上り下り 2 方向）のみとなっており E V は設置されていな い。また改札階からホームには、新たに E S C （上り下り 2 方向） と E V (通り抜け型）が設置された。この時点で、出入口と各ホー ムを結ぶ乗降動線において一般的な経路といえる主動線がバリア フリー化された。改札階については依然として工事中であり、券売 機、改札、案内表示等の設備は仮設となっている。改札は、 5 基か ら 6 基になり、そのうちの 1 基は拡幅改札となった。この時点でも、 駅舎内にはトイレが未設置であった。 


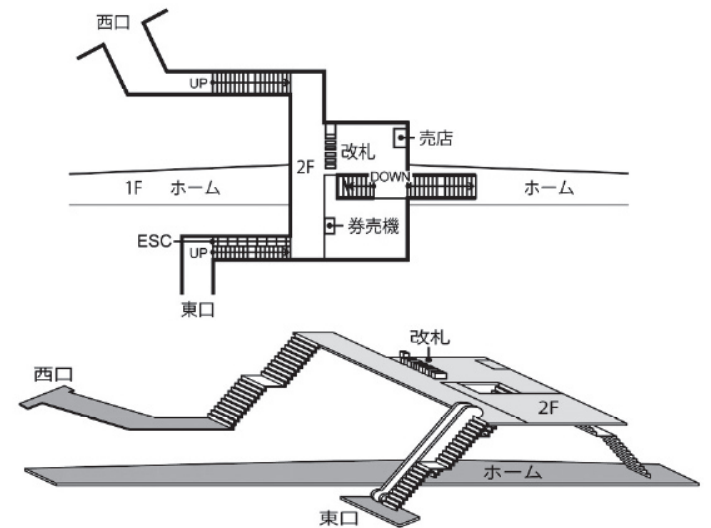

図 1 MK駅_改修前（2005 年）注7)

3 ） 2009 年 全面改修後一基本改修より約 3 年経過一（図 2) 2009 年 5 月、駅前広場を含む駅舎の全面改修が終了した。基本構 造や表 4 の網がけ部分の設備等は 2007 年調查時と同様であるが、 新たに駅構内に多機能卜イレが設置されたほか、簡易ベンチなど の休数設備も整備されている。

\section{4. 調査結果}

\section{4-1. 回答者の概要}

回答者の年齢は調査年で若干のばらつきがあるものの、20 代〜 80 代まで幅広く、また歩行能力については、約 8 割が「駆け足が できるなど、問題ない」と回答している（表 5 、表 6 )。また MK 駅の利用頻度については、「日常的に利用寸る（ほぼ毎日〜週 2 日 程度)」と回答した人が約 6 割、その他は「あまり利用しない（週 1 日程度〜年数回程度)」と回答している（表 7 ）。

以上より、本調查結果は「年代に因らず歩行能力には大きな問題 がなく、半数以上がMK駅を日常的に利用している」回答者による ものといえる。また、調査年と属性(年代、性別、歩行能力)および 回答者の駅利用頻度について、独立性の検定を行ったところ、有意 な差はみられなかったことから (年代; $\mathrm{P}$ 值=.400、性別; $\mathrm{P}$ 值=.604、 歩行能力; $\mathrm{P}$ 值 $=.097$ 、利用頻度 $; \mathrm{P}$ 值 $=.875$ )、調查年ごとの回答 者属性の偏りはないとして、以下論を進める（表 $5 \sim 8$ ）注8)。

\section{4-2. MK駅の利用のしやすさ総合評価の変化}

駅改修にともなう、バリアフリー等整備によって駅の利用のしや すさ総合評価は、「大変利用しやすい」及び「利用しやすい」と回 答した人が、2005 年の改修前の $23.7 \%$ から 2007 年の基本改修後 には $83.6 \%$ 、さらに全面改修後の 2009 年には $97.1 \%$ へと向上し ている。一方、「大変利用しづらい」、「利用しづらい」と回答した 人は 2005 年では $57.9 \%$ でったが、2007 年には $2.0 \%$ にまで減少 し、さらに 2009 年には $0 \%$ となっている（図 3 )。

回答者の年代、性別、歩行能力、駅利用頻度と総合評価について、 差の検定（マン・ホイットニーの $\mathrm{U}^{\text {注9) }}$ ) を行ったところ、属性に よる回答に有意な差はみられなかった（表 9 )。

駅の利用のしやすさの総合評価については、バリアフリー整備を 含む大規模改修が行われたことによって、性別、年代、歩行能力、 駅利用頻度などの利用者属性によらず、かなり向上していると言え る。

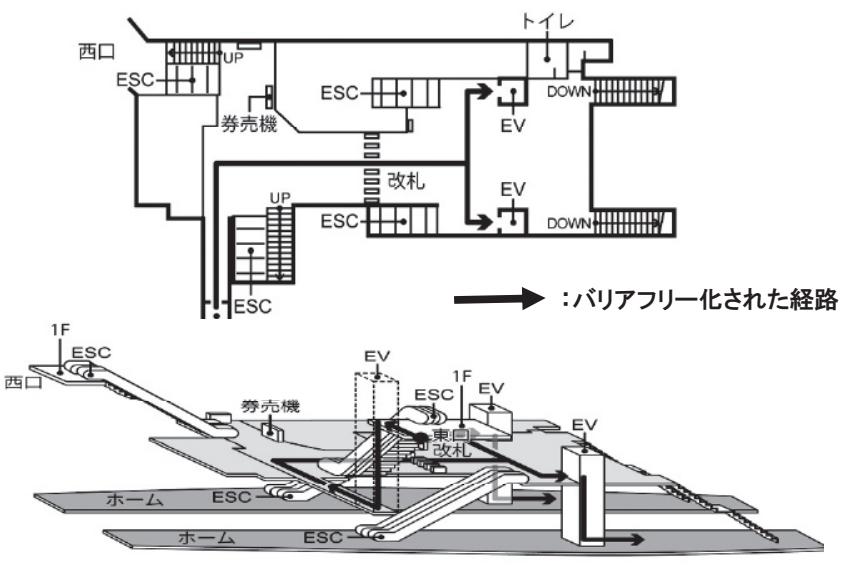

図 2 MK駅_改修後（2009 年）注 7)

表 5 回答者の年代

\begin{tabular}{lrlrlrl}
\multicolumn{1}{c}{2005 年 } & \multicolumn{1}{c}{2007 年 } & \multicolumn{2}{c}{2009 年 } \\
\hline 10 代 & $5.1 \%$ & $(2)$ & $0.0 \%$ & $(0)$ & $1.0 \%$ & $(1)$ \\
20 代 & $5.1 \%$ & $(2)$ & $16.2 \%$ & $(16)$ & $9.5 \%$ & $(10)$ \\
30 代 & $23.1 \%$ & $(9)$ & $19.2 \%$ & $(19)$ & $13.3 \%$ & $(14)$ \\
40 代 & $15.4 \%$ & $(6)$ & $13.1 \%$ & $(13)$ & $17.1 \%$ & $(18)$ \\
50 代 & $17.9 \%$ & $(7)$ & $16.2 \%$ & $(16)$ & $17.1 \%$ & $(18)$ \\
60 代 & $20.5 \%$ & $(8)$ & $17.2 \%$ & $(17)$ & $20.0 \%$ & $(21)$ \\
70 代 & $7.7 \%$ & $(3)$ & $15.2 \%$ & $(15)$ & $17.1 \%$ & $(18)$ \\
80 代 & $5.1 \%$ & $(2)$ & $3.0 \%$ & $(3)$ & $4.8 \%$ & $(5)$ \\
\hline \multicolumn{3}{c}{$\mathrm{n}=39$} & \multicolumn{3}{c}{$\mathrm{n}=99$} & \multicolumn{3}{c}{$\mathrm{n}=105$}
\end{tabular}

$\chi^{2}$ 值 $=14.681, \mathrm{P}=.400 \quad$ ()内の值は度数.

表 6 回答者の歩行能力

\begin{tabular}{lrrrrrr} 
& \multicolumn{2}{c}{2005 年 } & \multicolumn{2}{c}{2007 年 } & \multicolumn{2}{c}{ 2009年 } \\
\hline 駆け足ができ、歩行に問題なし & $82.1 \%$ & $(32)$ & $79.8 \%$ & $(79)$ & $80.0 \%$ & $(84)$ \\
駆け足はできず、手すり·杖等には一切頼らない & $10.3 \%$ & $(4)$ & $14.1 \%$ & $(14)$ & $19.0 \%$ & $(20)$ \\
手すり·杖は必要だが自立して歩行できる & $5.1 \%$ & $(2)$ & $6.1 \%$ & $(6)$ & $1.0 \%$ & $(1)$ \\
ほとんど自力で外出することはできない & $2.6 \%$ & $(1)$ & $0.0 \%$ & $(0)$ & $0.0 \%$ & $(0)$ \\
\hline & & $\mathrm{n}=39$ & & $\mathrm{n}=99$ & $\mathrm{n}=105$
\end{tabular}

$\chi^{2}$ 値 $=10.739, \mathrm{P}=.097 \quad()$ 内の值は度数

表 7 回答者のMK駅利用頻度

\begin{tabular}{|c|c|c|c|c|c|c|}
\hline \multirow[b]{2}{*}{ 日常的に利用している } & \multicolumn{2}{|c|}{ 2005年 } & \multicolumn{2}{|c|}{ 2007年 } & \multicolumn{2}{|c|}{ 2009年 } \\
\hline & $59.0 \%$ & (23) & $63.6 \%$ & (63) & $62.9 \%$ & (66) \\
\hline あまり利用しない & $41.0 \%$ & (16) & $36.4 \%$ & (36) & $37.1 \%$ & (39) \\
\hline
\end{tabular}

$\chi^{2}$ 值 $=0.267, \mathrm{P}=.875$ ()内の值は度数.

表 9 回答者属性別の総合評価

表 8 回答者の性別 差の検定結果

\begin{tabular}{|c|c|c|c|c|c|c|c|}
\hline & 2005年 & \multicolumn{2}{|c|}{ 2007年 } & \multicolumn{2}{|c|}{ 2009年 } & \multicolumn{2}{|c|}{ 童 } \\
\hline 男 & $28.2 \% \quad(11)$ & $34.3 \%$ & (34) & $37.1 \%$ & (39) & 年代 & -1.377 \\
\hline 女 & $71.8 \% \quad(28)$ & $65.7 \%$ & (65) & $62.9 \%$ & (66) & 性別 & -1.677 \\
\hline & $n=39$ & & $n=99$ & & $n=105$ & 歩行能力 & -1.677 \\
\hline & $008, P=.604$ & () 内 $\sigma$ & ＼cjkstart值は & & & 利用頻度 & -1.233 \\
\hline
\end{tabular}

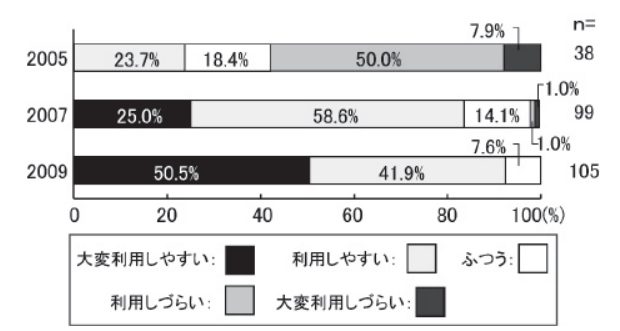

図 3 MK駅の利用のしやすさ総合評価（2005/2007/2009） 
その理由については、バリアフリー整備によって移動の円滑性が 向上したこと、ホーム柵等により安全性が向上したことなどが考え られるが、駅設備の要素別評価結果を踏まえ、後で詳しく考察する。

\section{4-3． 駅の施設要素別の利用のしやすさ評価の変化}

MK駅の駅施設要素別の利用のしやすさ評価(1：とても利用し づらい、 2 : 利用しづらい、 $3:$ ふつう、 4 : 利用しやすい、 5 : とても利用しやすい、の 5 段階評価)について、評価得点の平均值 を算出し、各調査年 $(2005,2007,2009)$ の間で差の検定注 ${ }^{10)}$ および 多重比較を行った（表 $10 、 11$ ）。平均值の変化としては、全般 的に改修後に評価が向上する傾向が読み取れるが、ホーム柵など、 一部に物的な状況は同じであっても評価が低下しているものも見 受けられる。差の検定および多重比較の結果から、2005 年から 2007 年の間に改修が行われた「駅出入口」「階段 $1 」 「 E$ S C $1 」$ 「階段 $2 」 「$ 電車とホームの段差・隙間」について、改修前 (2005 年）と改修後（2007、2009 年）の間での評価向上に有意な差がみ られた。また、2007 年時点では仮設であった「改札」「運賃表」「案 内表示」、2009 年に新設された「トイレ」についても同様に、改 修後（2009 年）とそれ以前（2005、2007 年）との間に有意な差 がみられた。一方、2007 年で新設された「ホーム椢」については、 前述の通り、2007 年と 2009 年とでは物的な状況は変わっていな いにもかかわらず利用者評価は低下し、その差も有意であった。

調査間で利用者評価に有意差が見られた駅施設要素について評 価の構成をより詳しくみると、2005 年から 2007 年の間で改修が 完了した要素（階段 1 、 E S C 1 、電車とホームの段差・隙間な ど）については、2007 年調査で「利用しやすい」の増加、「利用 しづらい」の減少といった顕著な評価向上傾向を示しているが、 その後の 2009 年調查では「利用しやすい」が減少し、「ふつう」 評価が増加している。その傾向は、2006 年に新設された「ホーム 柵」の 2007 年調查と 2009 年調査の評価結果において最も顕著に 現れているが、総じて改修・新設の直後の調査で「利用しやすい」 と評価されたものが、改修・新設から時間が経つにつれ「ふつう」 という評価に転じる傾向がみられる（図 4)。

以上について、利用者の年代、駅利用頻度、歩行能力によって その傾向が異なるか否かを明らかにするため有意差検定を行った が、殆どの施設要素評価において帰無仮説を棄却することにはな らなかった。すなわち、年代、駅利用頻度、歩行能力によらず、 改修・新設から時間が経つにつれ「ふつう」評価が増加する傾向
表 10 調查別(2005,2007,2009)の要素別利用評価一差の検定結果

\begin{tabular}{|c|c|c|c|c|c|c|c|c|}
\hline & \multicolumn{2}{|c|}{2005} & \multicolumn{2}{|c|}{2007} & \multicolumn{2}{|c|}{2009} & \multirow{2}{*}{\multicolumn{2}{|c|}{$\chi^{2}$ (またはZ) 値 }} \\
\hline & 平均 & 標準偏差 & 平均 & 標準偏差 & 平均 & 標準偏差 & & \\
\hline 駅出入口 & 2.36 & 0.99 & 3.37 & 0.90 & 3.50 & 0.75 & 38.86 & ** \\
\hline 階段1 & 2.31 & 1.00 & 3.32 & 0.87 & 3.32 & 0.79 & 34.33 & ** \\
\hline ESC1 & 2.49 & 1.02 & 3.59 & 1.02 & 3.46 & 0.86 & 29.44 & ** \\
\hline EV1 & - & - & 3.02 & 1.07 & 3.28 & 1.09 & -1.49 & \\
\hline 運賃表 & & & 2.96 & 0.75 & 3.90 & 1.48 & -4.60 & \\
\hline 券売機 & 2.97 & 0.63 & 3.03 & 0.68 & 3.62 & 1.41 & 1.63 & \\
\hline 改札 & 2.69 & 0.92 & 3.19 & 0.89 & 3.31 & 0.74 & 14.61 & ** \\
\hline 案内表示 & 2.62 & 0.85 & 3.02 & 0.81 & 3.35 & 0.69 & 24.83 & ** \\
\hline トイレ & 2.23 & 1.75 & 2.91 & 1.70 & 3.43 & 1.16 & 64.17 & ** \\
\hline 階段2 & 1.54 & 0.64 & 3.01 & 0.74 & 3.20 & 0.63 & 95.08 & ** \\
\hline ESC2 & - & - & 3.27 & 1.04 & 3.24 & 0.77 & -0.24 & \\
\hline EV2 & - & - & 3.33 & 1.03 & 3.34 & 0.84 & -0.09 & \\
\hline ホーム & & & 3.52 & 0.83 & 3.47 & 0.73 & -0.63 & ** \\
\hline ホーム柵 & - & - & 4.16 & 0.72 & 3.64 & 0.74 & -5.02 & ** \\
\hline $\begin{array}{c}\text { 電車とホーム } \\
\text { の段差隙間 }\end{array}$ & 2.97 & 0.71 & 3.84 & 0.79 & 3.43 & 0.62 & 41.96 & ** \\
\hline
\end{tabular}

※階段、E S C、E Vについては、出入口ー改札間に設置されているものを 「階段 $1 」 「 \mathrm{E} \mathrm{S} \mathrm{C} 1 」 「 \mathrm{E} \mathrm{V} 1$ 」、改札階一ホームに設置されているものを

「階段 $2 」 「 E$ S C $2 」 「 E$ V $2 」$ と表記している。* ${ }^{*}$ p $<.01 、 * *: p<.05$

表 11 調查年別の多重比較結果

\begin{tabular}{|c|c|c|c|c|c|c|c|c|c|}
\hline & \multicolumn{3}{|c|}{ 駅出入口 } & \multicolumn{3}{|c|}{ 階段 1} & \multicolumn{3}{|c|}{ ESC1 } \\
\hline & 2005 & 2007 & 2009 & 2005 & 2007 & 2009 & 2005 & 2007 & 2009 \\
\hline 2005 & - & $26.670^{* *}$ & 35.298 * & - & $28.784^{* *}$ & $26.909^{\text {** }}$ & - & $26.701^{* *}$ & $19.385^{* *}$ \\
\hline 2007 & & - & 0.9880 & & - & 0.089 & & - & 1.186 \\
\hline 2009 & & & - & & & - & & & - \\
\hline
\end{tabular}

\begin{tabular}{|c|c|c|c|c|c|c|c|c|c|}
\hline & \multicolumn{3}{|c|}{ 改札 } & \multicolumn{3}{|c|}{ 案内表示 } & \multicolumn{3}{|c|}{ トイレ } \\
\hline & 2005 & 2007 & 2009 & 2005 & 2007 & 2009 & 2005 & 2007 & 2009 \\
\hline 2005 & - & 8.045 & $12.965^{* *}$ & - & 3.628 & $19.679^{* *}$ & - & 3.430 & $46.599^{* *}$ \\
\hline 2007 & & - & 1.004 & & - & $11.475^{* *}$ & & - & 42.179 ** \\
\hline \multirow{3}{*}{2009} & & & - & & & - & & & - \\
\hline & & 階段2 & & 電車 & ホームの段 & 差·隙間 & \multirow{5}{*}{\multicolumn{2}{|c|}{$*: p<.01 、 * *$}} & \\
\hline & 2005 & 2007 & 2009 & 2005 & 2007 & 2009 & & & \\
\hline 2005 & - & $68.982^{\text {** }}$ & $88.093^{* *}$ & - & $36.191^{* *}$ & $8.971^{* *}$ & & & $p<.05$ \\
\hline 2007 & & - & 1.912 & & - & 17.200 & & & \\
\hline 2009 & & & - & & & - & & & \\
\hline
\end{tabular}

があると言える。その理由としては、(1)基本改修から 2 年が経過 し、現在の駅舎環境が日常化し「当たり前」になったこと、(2)他の 駅でもバリアフリー整備が進められているなど、社会全体としての 整備レベルが向上し注 ${ }^{11)}$ 、それに伴い利用者自身の評価基準があが ってきていることの 2 つ側面があると考えられる。

川内 ${ }^{9)}$ はユニバーサルデザインの特徴の 1 つとして、「インビジブ ル（invisible=目に見えない、目立たない）」であることを指摘し、 またスパイラルアップについては「利用者のニーズは時間とともに 次第に高度になっていき (後略)」と述べている。「ふつう」評価が 増加する理由の 2 つ側面はその表れであると考察できる。
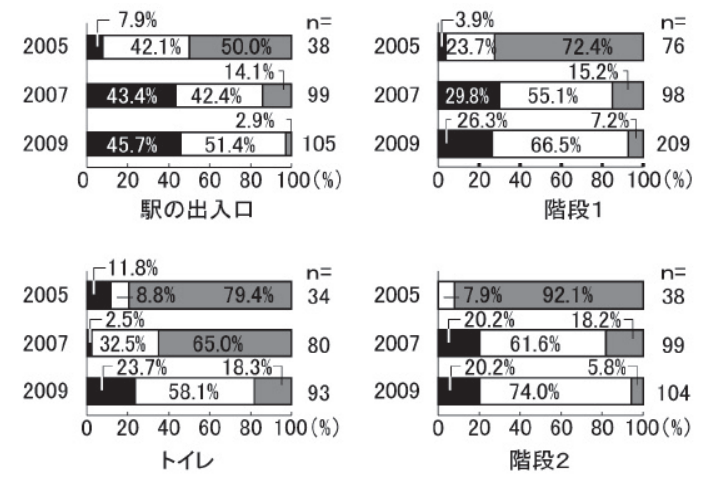
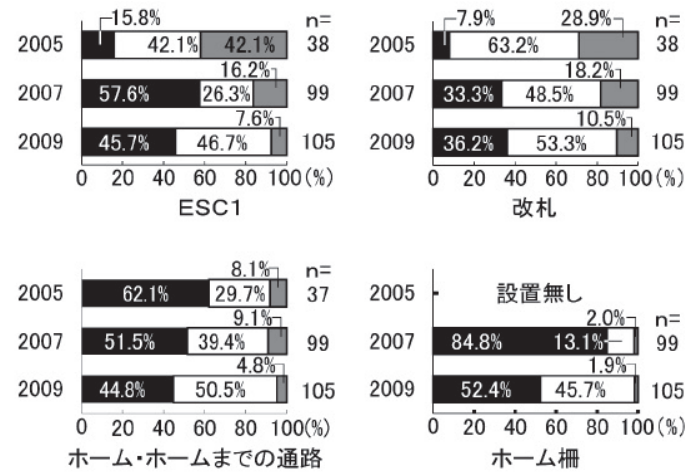

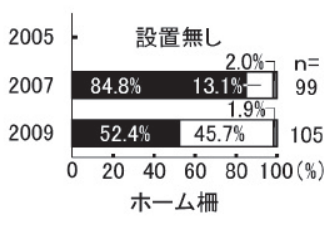

凡例）利用しやすい:
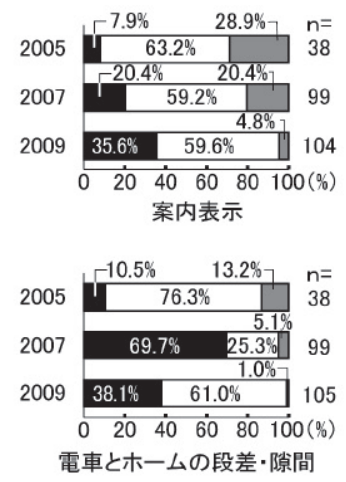

図 4 MK駅の利用のしやすさ要素別評価（2005/2007/2009） 


\section{4-4. 駅施設利用者の評価構造と総合評価の関係}

バリアフリー整備を含む大規模改修が行われたことによって地 域住民による MK 駅の「利用のしや寸さ」評価が向上しているこ とは先に述べた通りであるが、その「利用のしや寸さ」評価はど のような評価要因（潜在的因子）によって構成されているのか、 またそれら要因と総合評価との関係はどうなっているのかを明ら かにするため共分散構造分析を行った注 ${ }^{12)}$

まず、潜在的な評価因子を探るため、空間としての性格の違い （改札外、改札内、ホームなど）と駅施設に求められる性能・機能 の違い（安全性、移動円滑性（垂直移動、水平移動）、案内情報等 のわかりやすさなど）に基づく潜在的変数を候補として仮定し、 探索的に確認的因子分析を繰り返し、個別のパスに関する符号条 件や共分散構造分析で用いられる代表的な適合度指標注 13) GFI (Goodness of Fit Index)、AGFI(Adjusted GFI)、RMSEA(Root Mean Square Error of Approximation)を考慮し、推計精度が高 くなるように潜在的変数とモデル構造を選択した。図 $5 、 6$ に 2005 年調查に基づく改修前の評価要因の因果関係モデル（以下、 関係モデル）と 2009 年調査に基づく全面改修後の関係モデルを 示す注 14)。2 2005 年（改修前）のモデル（図 5 ）は、適合度指標 から判断すると十分な適合を示しているとは言えないが、改修後 の評価モデル（図6）とはその構造が異なっていると考えられた ため、その比較参考として示した注 ${ }^{15)}$ 。

全面改修後の関係モデル（図 6 ) と改修前の関係モデル（図 5 ） を比較すると、全面改修後の関係モデルでは「ホームの安全性」 「情報のわかりやすさ」「移動の円滑性」など、駅施設に求められ る機能・性能によって駅施設の「利用のしやすさ」が評価される 傾向が表されているが、改修前の関係モデルでは「改札外空間の 移動性・利用性」「改札内空間の移動性」といった性格の異なる空 間評価にかかわる潜在的因子が選択された。改修前の駅舎は橋上 駅であり、また交通系 IC カード導入前であったため、駅利用の行 為が垂直移動（昇り）－改札（溜まり）？垂直移動（下り）のよう に分断されていたことが影響し、全面改修後の地下駅では、垂直移 動行為が「昇り」か「下り」の一方向となると共に ESC、EV が整 備され、また交通系 IC カードが導入されるなど、移動の連続性が 確保されたため、移動・利用行為にかかわる性能、機能が潜在的評 価因子となったと思われる。

全面改修後の関係モデルを詳しく見ると、「駅の利用のしやすさ」 は「ホームの安全性」「情報のわかりや寸さ」「移動の円滑性」の 3 因子十「トイレ」の評価によってなされており、その中でも「移動 円滑性」が「駅の利用のしやすさ (総合評価)」に最も影響を与えて いる（標準化係数：0.72）ことが表れている。その「移動円滑性」 には「ESC」「EV」「階段」「駅出入口」の利用のしやすさがほぼ同 等（係数 $0.7 \sim 0.8 ）$ に影響していることが示されている。アンケー 卜調査の自由記述において「E S C、E V ができたことで便利にな った」という意見が多数みられたと同時に「E S C、E V、階段が 混雑する」という問題指摘も多かったことから鉄道駅における「移 動円滑性」評価を総合的に向上させるためには単に「ESC」や「EV」 を整備すれば良いわけではないと推察できる。

他の評価構成因子とした「ホームでの安全性」「情報のわかりやす さ」と「駅の利用のしやすさ」評価との関係はあまり強くない結果

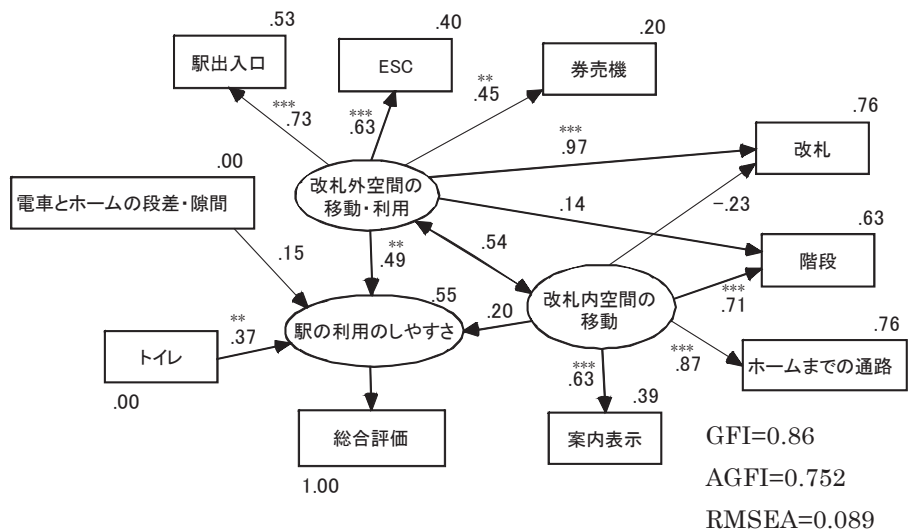

図 52005 年調查に基づく改修前の評価要因の因果関係モデル

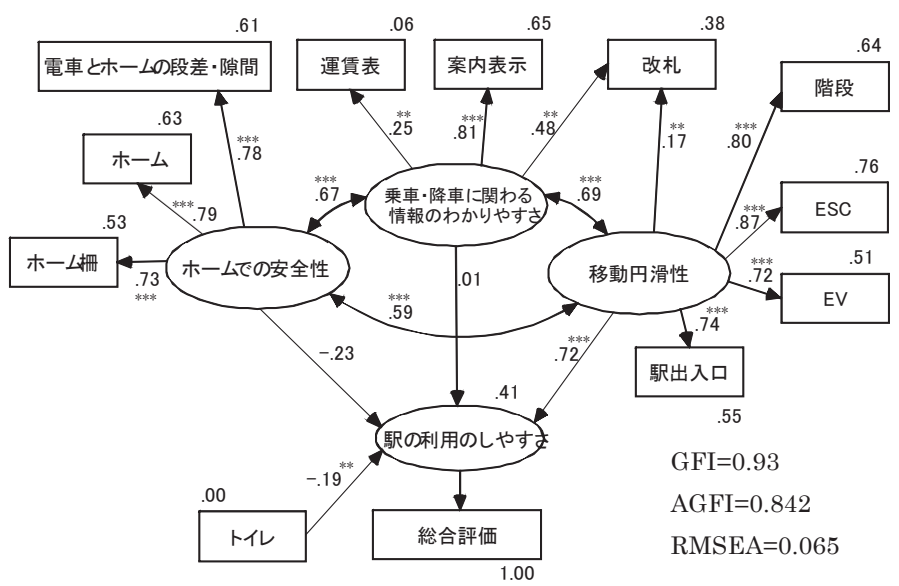

図 62009 年調査に基づく改修後の評価要因の因果関係モデル ·誤差変数の標記は省略 •図中のパスに近接した数字：標準化係数 ・パスの有意水準：***: $1 \%$ 有意 $* *$ : $5 \%$ 有意

となった。その理由として、「ホームでの安全性」は鉄道駅における 当たり前の要求となっていること、「情報のわかりやすさ」について は、生活駅利用者の殆どはその環境を熟知していること、また交通 系 IC カードの普及によって運賃表に代表される乗車・降車時の「情 報のわかりやすさ」はあまり意識されなくなったことが考えられる。 「トイレ」については構内に新しく整備されたことによって、トイレ そのものの評価は向上しているが、それが駅施設の総合評価を上げ る要因とはなっていない。駅構内のトイレは必ず使用しなければな らないものではない。駅にある「公衆トイレ」と考えれば、「駅の利 用のしやすさ」に直接的は関係しないと理解することも可能である。

\section{5. まとめと今後の課題}

本研究では、バリアフリー法において生活関連施設として重要な 位置にある鉄道駅施設を対象として、バリアフリー環境整備前後に おける駅利用者の環境評価の変化を明らかにすることを目的として、 駅周辺住民に対するアンケート調査とその分析を行った。

以下に調査分析から得られた結果をまとめる。

( 1 ) バリアフリー環境整備を含む大規模改修が行われたことによっ て、駅利用のしやすさの総合的評価は、性別、年代、歩行能力、駅 利用頻度などの利用者属性によらず向上している。

（2）一方、駅施設要素別に見た場合、改修・新設直後には「利用し 
や寸い」と評価されていたものが、時間が経つにつれ「利用しやす い」が減少し、「ふつう」評価が増加する傾向がある。

（３）駅施設全面改修後の利用者評価は、「ホームの安全性」「情報の わかりやすさ」「移動の円滑性」十「トイレ」の評価によってなされ ており、その中でも「移動の円滑性」が「駅の利用のしやすさ（総 合評価)」に最も影響を与えており、その「移動の円滑性」には「ESC」 $「 \mathrm{EV} 」 「$ 階段」「駅出入口」の利用のしや寸さがほぼ同等に影響して いる。

以上の結果から、バリアフリー法に基づくバリアフリー環境整備 によって駅利用のしやすさは確実に向上している。但し、5 (2)で述 べたように、移動・利用円滑化のための環境整備によって一度「使 いやすい」と評価されたものが、時間経過と共に「ふつう」評価に 低下寸る場合があることも明らかになった。利用者の視点に立った スパイラルアップの環境改善を実践していくために住民アンケート などを実施する場合には、単に「ふつう」評価を聞くのではなく、 「問題なく当たり前の配慮」として捉えられているのか、「可もなく 不可もなく」と評価されているのか、或いは「利用者ニーズが高度 化した表れ」なのかを把握できるようにすることが必要であろう。

なお、今回の調査対象者は高齢者を含む健常者が主であったため、 「改善整備された施設によって、ある特徴をもつ利用者にとっての 問題は解決されたが、それ以外の特徴を持った人にとっての問題は 改善されていない場合、あるいは逆に使いづらさを助長している場 合」などの実態については明らかになってはいない。今後の課題と して研究を継続する予定である。

\section{謝辞}

アンケート調查にご協力くださったMK駅周辺住民の方々、また調 查実施に関し、花塚明菜さん、渡部綾乃さん（当時、日本女子大学 住居学科）の協力を得ました。ここに記して感謝の意を表します。

注

注 1) 金田他（2008）10）は国土交通省に届け出のあった交通バリアフリー 基本構想（平成 18 年 12 月 31 日現在、 260 件）について、基本構想 策定後の事業の進行管理や事後評価の提示状況を調查している。その 結果によると、260 件中、「P D C A サイクルによる継続的な推進活 動」を行っている事例が 4 件、「アウトカム指標によるバリアフリー 化の評価を実施」、利用者からの意見聴取やアンケートにより事業実 施や評価のフォローアップを行う」等の事例が 2 件、「計画段階から の意見反映システムの構築、施設共用後もモニタリング活動を実施す ることにより、常に利用者の意見をフィードバックできる体制を検 討」している事例が 1 件となっている。

注 2）本研究における「バリアフリー未整備」とは、出入口から各ホーム を結ぶ乗降動線について、バリアフリー法でいう「移動円滑化経路」 が確保されていない状態、としている。

注 3) 本研究でいう「基本改修」とは、駅構造の改修およびバリアフリー 経路確保のために、垂直移動手段（階段、E S C、E V ) が改修・新 設されたことを指す。詳細は「3.調査対象駅のバリアフリー状況 2) 2007 年調查時; 基本改修後」を参照のこと。

注 4）生活駅とは、大都市近郊の拠点地域かつ駅周辺が住宅中心となって いる駅であり、主に通勤通学利用者が大半を占める駅のことである (「街と一体となっただれもが利用しやすい利便性・快適性の高い駅 等の交通ターミナルの整備方策」報告書 pp. 82、「4-1 駅分類の設定」 平成 14 年 3 月国土交通省)。
注 5）品川区ホームページ「品川区の統計〜駅別 1 日乗降者人員」 http://www. city. shinagawa. tokyo. jp/ct/other000009400/all04. xls 東急電鉄ホームページ 各駅乗降人員を参考に作成。

http://www. tokyu. co. jp/railway/railway/west/gaiyou/joukou. html\# meguro

注 6）要素別評価項目の「トイレ」の利用評価は 2005、2007 年調査時には 駅構内にトイレの設置がなかったため、駅前にあるトイレを評価した ものである。2009 年は駅構内に新設されたトイレ（多機能トイレを 含む）の評価である。

注 7）東急電鉄のホームページ各駅情報を基に作成。 http://www. tokyu. co. jp/railway/railway/train/shisetsu/shisetsu_ musashikoyama. html

注 8）独立性の検定を行い、分割表に期待度数 5 未満のセルがある場合は 漸近有意確立の信頼性が低くなるため、正確確立検定により P 值の算 出を行っている。

注 9）マン・ホイットニーのU検定とは、2つの ‘対応なし’「順序尺度」 データの「中央值」の差を検定する手法で、外れ值が存在していたり、 データの正規性が保証されなかったりする場合でも分析可能である。 ちなみに、3つ以上の ‘対応なし’「順序尺度」データの場合はクラ スカル・ウォリス検定を用いている。

注 10) 要素別評価において、2007 年で新設された要素については 2007 年と 2009 年の 2 回のみの調査であるため、マン・ホイットニーの U 検定 を、その他、2005, 2007, 2009 の 3 回調査している要素においては、 クラスカル・ウォリスの検定を用いている。

注 11) 国土交通省ホームページ

http://wwwtb. mlit.go.jp/kanto/youran_cgi/pdf/08/08_tc_001.pdf 「鉄軌道駅におけるバリアフリー化への対応状況」より、本研究での 調查年における「段差の解消」「E V、E S C の整備状況」は以下の とおり、推移している。

\begin{tabular}{lccc} 
& 2005 & 2007 & 2009 \\
\hline 段差への対応状況 & $56 \%$ & $75 \%$ & $78 \%$ \\
エレベーター整備状況 & $69 \%$ & $79 \%$ & $84 \%$ \\
エスカレーター整備状況 & $71 \%$ & $73 \%$ & $74 \%$ \\
\hline ※1日あたりの平均利用者数が5 千人以上の総鉄軌道駅数に対する割合
\end{tabular}

なお、 1 日当たりの平均利用者数が 5 千人以上の駅において (平成 21 年 3 月現在)、「車い寸使用者対応型トイレ設置駅」が $84 \%$ 、「視覚障 害者用誘導ブロック設置駅」が 99\%、「拡幅改札口設置駅」が 96\%、 「身体障害者対応券売機設置駅」が $81 \%$ 、「転落防止のための設備設 置駅」が 99\%となっている。

注 12) 共分散構造分析には Amos 7.0 を用いている。

注 13) GFI (Goodness of Fit Index)は、一般的には 0.90 より大きいと、 当てはまりのよいモデルとされる。AGFI (Ad justed GFI) は GFI を修正 した值であり、GFI よりも小さい值となる。RMSEA(Root Mean Square Error of Approximation) は一般的に 0.05 以下であればあてはまりが よく、0.10以上であれば当てはまりがよくないとされる。

注 14) 2007 年調査については「改修途中」であるため本稿では比較対象と して取り上げてはいないが、因果関倸の基本構造は2009 年調査に基 づく全面改修後の関係モデルと類似している。すなわち、「駅の利用 のしや寸さ」には 2009 年調査の分析と同様に「移動円滑性」が最も 影響を与えている（標準化係数：0.80）こと、他の要因（ホームでの 安全性: 標準化係数 .081、情報のわかりやすさ: 標準化係数 -. 075、 トイレ : 標準化係数 -.012) は「駅の利用のしやすさ」評価との関係 はあまり強くないことが示されている。

注 15) 全面改修後の 2009 年の調査データを改修前の関係モデル構造に合わ せ分析したが、その適合度は著しく低かった (GFI $=0.72 、 A G F I=0.62 、$ RMSEA=0.15)。そのため、今回対象とした MK 駅においては、改修前後 での評価構造は異なっていると判断した。尚。改修前の 2005 年調查 は、その実施時点で $E V$ やホーム柵が設置されていないなど、2009 年 調查（全面改修後）とは一部の調查項目が異なっている。そのため 
2005 年調査を基に改修後の因果関係モデルの構造にあわせた比較は 行っていない

\section{参考文献}

1）山田稔，澤村里志: 交通バリアフリー法基本構想策定における市民参 加プロセスの実態 策定済み自治体アンケートの結果から, 土木計画 学研究・講演集 31 巻, pp. 93-96, 2005

2）谷内久美子, 北川博巳 : 交通バリアフリー基本構想の今後の課題、日 本福祉のまちづくり学会第 9 回全国大会概要集, pp. 209-212, 2006

3）山田稔，澤村里志 : 交通バリアフリー法基本構想策定における市民 参加の実態と行政担当者への理解促進効果, 土木学会土木計画学研 究・論文集 23 巻, pp. 1057-1064, 2006

4）桐生義春, 山田一信、伊藤健次他：つくばエクスプレスの駅施設ユ ーザー評価、日本建築学会大会学術講演梗概集 E-1, pp. 821-822, 2006.9

5）磯部友彦 : バリアフリー化された鉄道駅内の昇降装置の設置効果、 土木計画学研究・講演集 31 巻, pp. 95-98, 2005

6）加藤浩徳, 芝海潤, 林淳, 石田東生 : 都市鉄道駅における乗換利便性 向上施策の評価手法とその適用、土木学会年次学術講演会講演概要集 第 4 部 55 巻, pp. 758-759, 2000

7）山岡俊一: 地方部の福祉型鉄道駅のあり方に関する調査研究-JR 呉線 新広駅を事例に-，日本福祉のまちづくり学会第 6 回全国大会概要 集，pp. 99-102，2003

8）萬直樹，高橋清，佐藤馨一: 高齢者の地下鉄駅利用特性に関する研究、 土木学会年次学術講演会講演概要集第 4 部, 46 巻 pp. 34-35, 1991

9）川内美彦：ユニバーサル・デザインの仕組みをつくるースパイラルア
ップを実現するためにー，学芸出版社，2007.7

10）金田敏彦，立川宏 : バリアフリー基本構想に関する考察－1一交通バ リアフリー基本構想の記載内容—, 日本福祉のまちづくり学会第 11 回全国大会概要集, pp. 397-340, 2008

11）川内美彦：ユニバーサル・デザインにおける「継続的改善」のモデル 化に関する研究—ユニバーサル・デザインを目指したまちづくりに関 する研究一, 日本建築学会計画系論文集, 第 603 号, pp. 97-103, 2006.5

12）国土交通省総合政策局安心政策課 : 公共交通機関の旅客施設に関する 移動等円滑化整備ガイドライン，2007.7

13）山本昌和, 青木俊幸, 外山直也 : 鉄道駅のユニバーサルデザイン評価 に関する研究, 日本建築学会大会学術講演梗概集 E-1, pp. 819-820, 2006. 9

14）薄田勝典, 山根清香, 青木俊幸, 古賀和博, 河合邦治, 山本 昌和, 佐藤隆 : 移動制約者に配慮した鉄道の計画に関する研究 その 3 高齢 者の駅利用に関する意識, 日本建築学会大会学術講演梗概集 $\mathrm{E}-1$, pp. 889-890, 2006.9

15）早川昌毅、磯部友彦: 移動特性の違いを考慮した交通施設のバリアフ リ一化に対する利用者意識構造分析, 土木学会年次学術講演会講演概 要集第 4 部, 57 巻 pp. 35-36, 2002

16）豊田秀樹：共分散構造分析 [Amos 編 $]$ 一構造方式モデリングー，東 京図書，2007.5

17）小島隆矢 : Excel で学ぶ共分散構造分析とグラフィカルモデリング, オーム社, 2003

（2009年12月10日原稿受理，2010年 2 月19日採用決定） 